Original Article

\title{
Gender-based incidence, recovery period, and mortality rate of COVID-19 among the population of district Attock, Pakistan
}

\author{
Incidência baseada em gênero, período de recuperação e taxa de mortalidade de \\ COVID-19 entre a população do distrito de Attock, Paquistão
}

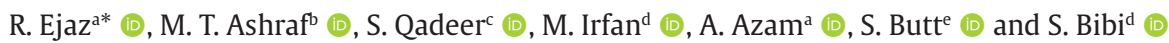 \\ aShaheed Benazir Bhutto Women University, Department of Zoology, Peshawar, Pakistan

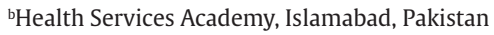 \\ 'University of Education, Division of Science and Technology, Department of Zoology, Lahore, Pakistan \\ dPir Mehr Ali Shah, Arid Agriculture University, Department of Zoology, Rawalpindi, Pakistan \\ eShaheed Benazir Bhutto Women University, Department of Microbiology, Peshawar, Pakistan
}

\begin{abstract}
COVID-19 is reported as an extremely contagious disease with common symptoms of fever, dry cough, sore throat, and tiredness. The published literature on incidence and gender-wise prevalence of COVID-19 is scarce in Pakistan. Therefore, the present study was designed to compare the distribution, incubation period and mortality rate of COVID-19 among the male and female population of district Attock. The data were collected between 01 April 2020 and 07 December 2020 from the population of district Attock, Pakistan. A total of 22,962 individuals were screened and 843 were found positive for RT-qPCR for SARS-CoV-2. The confirmed positive cases were monitored carefully. Among the positive cases, the incidence of COVID-19 was $61.7 \%$ among males and $38.2 \%$ among females. The average recovery period of males was $18.89 \pm 7.75$ days and females were $19 \pm 8.40$ days from SARS-CoV- 2 . The overall mortality rate was $8.06 \%$. The death rate of male patients was significantly higher $(\mathrm{P}<0.05)$ compared to female patients. Also, the mortality rate was higher $(\mathrm{P}<0.05)$ in male patients of 40-60 years of age compared to female patients of the same age group. Moreover, the mortality rate significantly increased $(\mathrm{P}<0.05)$ with the increase of age irrespective of gender. In conclusion, the incidence and mortality rate of COVID-19 is higher in males compared to the female population. Moreover, irrespective of gender the mortality rate was significantly lower among patients aged $<40$ years.
\end{abstract}

Keywords: COVID-19, Attock, mortality rate, gender, recovery period.

\begin{abstract}
Resumo
Covid-19 é relatada como uma doença extremamente contagiosa com sintomas comuns de febre, tosse seca, dor de garganta e cansaço. A literatura publicada sobre incidência e prevalência de Covid-19 com base no gênero é escassa no Paquistão. Portanto, o presente estudo teve como objetivo comparar a distribuição, o período de incubação e a taxa de mortalidade de Covid-19 entre a população masculina e feminina do distrito de Attock. Os dados foram coletados entre 1 de abril de 2020 e 7 de dezembro de 2020 da população do distrito de Attock, Paquistão. Um total de 22.962 indivíduos foi selecionado, e 843 foram considerados positivos para RT-qPCR para SARS-CoV-2. Os casos positivos confirmados foram monitorados cuidadosamente. Entre os casos positivos, a incidência de Covid-19 foi de $61,7 \%$ no sexo masculino e $38,2 \%$ no feminino. O período médio de recuperação dos homens foi de $18,89 \pm 7,75$ dias e das mulheres $19 \pm 8,40$ dias do SARS-CoV-2. A mortalidade geral foi de $8,06 \%$. A taxa de mortalidade de pacientes do sexo masculino foi significativamente maior $(\mathrm{P}<0,05)$ em comparação com pacientes do sexo feminino. Além disso, a taxa de mortalidade foi maior $(\mathrm{P}<0,05)$ em pacientes do sexo masculino com 40-60 anos de idade em comparação com pacientes do sexo feminino da mesma faixa etária. Além disso, a taxa de mortalidade aumentou significativamente $(\mathrm{P}<0,05)$ com o aumento da idade, independentemente do sexo. Em conclusão, a incidência e a taxa de mortalidade de Covid-19 são maiores no sexo masculino em comparação com a população feminina. E também, independentemente do sexo, a taxa de mortalidade foi significativamente menor entre os pacientes com idade $<40$ anos.
\end{abstract}

Palavras-chave: COVID-19, Attock, taxa de mortalidade, gênero sexual, período de recuperação.

*e-mail: rabeaejaz29@gmail.com

Received: February 25, 2021 - Accepted: May 26, 2021

This is an Open Access article distributed under the terms of the Creative Commons Attribution License, which permits unrestricted use, distribution, and reproduction in any medium, provided the original work is properly cited. 


\section{Introduction}

Coronavirus disease 2019 (COVID-19) is a human infectious disease caused by a novel coronavirus identified as severe acute respiratory syndrome coronavirus 2 (SARS-CoV-2); Zhu et al., 2020). The outbreak of this disease occurred in Wuhan a Hubei Province city of China (Huang et al., 2020; Guan et al., 2020) and the infection rate has shown massive growth in a short time. The lack of specific vaccines and antivirals hinder clinical strategies to control the disease (Campos et al., 2020). World Health Organization (WHO) declared COVID-19 a public health emergency on 30 January 2020 due to its rapid spread. On March 11, 2020, the epidemic had spread globally and was declared a pandemic by WHO (2020). A study of the first cases in China indicates the average incubation period between 2 to 7 days and the longest incubation period of 12.5 days (Omolo et al., 2020). However, in general, the incubation period of COVID-19 is considered as 1-14 days. The common symptoms include fever, dry cough, and tiredness though some individuals remain asymptomatic throughout the period. Asymptomatic patients are considered to be a potential source of infection (Rickman et al., 2021). Previous studies have reported a considerably high mortality rate of $4.3 \%$ to $30 \%$ (Li et al., 2020; Wang et al., 2020a, b; Zhou et al., 2020; Chen et al., 2020b; Bikdeli et al., 2020).

China was the epicenter of the COVID-19 pandemic, followed by Europe and the USA. The index case in Pakistan was reported on 26 February 2020 in a patient with a travel history from Iran (Arab News PK, 2020). Pakistan, with a unique challenge of highly porous borders, is sandwiched between two epicenters of Corona - China and Iran. Pakistan has a weak health infrastructure. Although The country recently strengthened their preparedness against COVID-19 by policy formulation and the implementation of national emergency preparedness, mandatory thermal screenings at all points of entries, and surveillance and contact tracing through data collection (Mughal, 2020). But in Pakistan, no published literature is available on the prevalence or incidence of COVID-19. According to the data compiled by the government of Pakistan, $11,377,42$ individuals were tested out of which the confirmed COVID-19 cases are 778,238 and 16,698 deaths were reported (https://covid.gov.pk/). Although the clinical characteristics of COVID-19 have been studied previously (Huang et al., 2020) the information regarding the gender-wise incidence and mortality with COVID-19 is limited. Human males are reported to have a more viral, bacterial, and fungal infection (Klein and Flanagan, 2016; Flanagan et al., 2017), weak innate and adaptive immune system (Ruel et al., 2011; Abdullah et al., 2012), more angiotensin-converting enzyme 2 (ACE2) receptors (Cai, 2019; Zhao et al., 2020) and have immunosuppressive sex hormone, testosterone (Klein et al., 2015) that make them more vulnerable to different comorbidities including COVID-19. Therefore, the present study was designed to compare the incidence and mortality rate of COVID-19 among the male and female population of district Attock, Pakistan to findout which gender and age group is more vulnerable for the disease.

\section{Materials and Methods}

\subsection{Setting and data source}

This retrospective hospital-based observational study used data from 01 April 2020 to 07 December 2020. A total of 22,962 suspected individuals for COVID-19 visited Government hospitals and laboratories in District Attock, Pakistan from 01 April 2020 to 07 December 2020. The patients were suspected if they had anyone or combination of symptoms like, fever, respiratory distress, dry cough, sore throat, lung infection, vomiting, nausea, diarrhea, fatigue and/or abnormal hematological parameters. The patients were also suspected based on exposure to the COVID-19 patient or living or visited an area of high incidence. The patients that had influenza and other common respiratory infections were excluded.

Nasal and pharyngeal swab specimens were taken and tested for coronavirus nucleic acid by using real-time reverse-transcriptase polymerase chain reaction assay (RT-qPCR). Patients with one positive RT-qPCR test for SARS-CoV-2 were considered to have confirmed COVID-19. Data of age and gender were collected from all patients. The confirmed positive cases for COVID-19 were followed for recovery. The recovery period in days was confirmed if the individual test was once found negative for RT-qPCR for SARS-CoV-2. Data on the total number of deaths were also recorded with the age and gender of deceased persons.

\subsection{Statistical analysis}

Data on the incidence and mortality rate of COVID-19 are presented in percentages. The comparison based on gender and age groups was done by a Chi-square test using SPSS software. The comparison of recovery period between male and female population was done by T-test using SPSS software. Values were considered significant with $\mathrm{p}<0.05$.

\section{Results}

\subsection{Prevalence, recovery period, and mortality rate of COVID-19}

Data on incidence, recovery period, and mortality rate of COVID-19 are shown in Table 1 . A total of $3.6 \%$ of individuals (843 positive cases /22,962 total screened) were found affected from COVID-19. Among confirmed positive cases, the incidence

Table 1. Incidence, recovery period, and mortality rate of COVID-19 among patients visiting different hospitals $(\mathrm{n}=22,962)$ of district Attock, Pakistan.

\begin{tabular}{cccc}
\hline & $\begin{array}{c}\text { Incidence } \\
\text { (\%) }\end{array}$ & $\begin{array}{c}\text { Recovery } \\
\text { Period } \\
\text { (days) }\end{array}$ & $\begin{array}{c}\text { Mortality } \\
\text { rate (\%) }\end{array}$ \\
\hline Males & 61.09 & 18.89 & $60.29^{\mathrm{a}}$ \\
Females & 38.90 & 19.02 & $39.7^{\mathrm{b}}$ \\
Overall & 3.67 & 19 & 8.06 \\
\hline
\end{tabular}

The values with different superscript within the same column differ significantly $(\mathrm{P}<0.05)$. a=mortality rate in males is significantly higher than females $b=$ mortality rate in females in significantly lower than males 


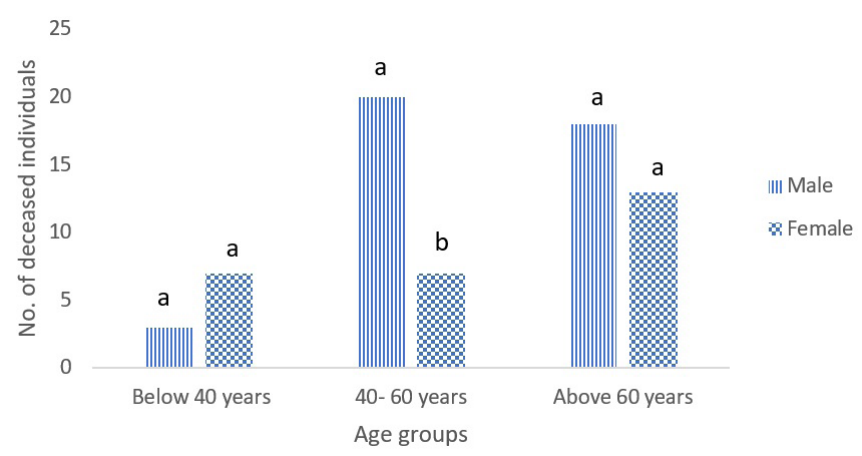

Figure 1. Gender-based mortality rate among COVID-19 confirmed cases $(n=843)$ in different age groups visiting different hospitals of district Attock, Pakistan. Bars with different letters differ significantly $(\mathrm{p}<0.05)$.

of COVID-19 was more in males ( 515 cases; $61.09 \%$ of total) compared to females ( 328 cases; $38.90 \%$ of total). The average recovery period of males was $18.89 \pm 7.75$ days and in female was $19 \pm 8.40$ days from SARS-CoV-2. Total deceased cases were 68 . The mortality rate among the male population (41 cases; $60.29 \%$ ) was significantly higher $(\mathrm{P}<0.05)$ than the female population (27 cases; 39.7\%) of district Attock.

\subsection{Effect of age on the mortality rate of COVID-19}

Data on the mortality rate of COVID-19 among different age groups of male and female patients are presented in Figure 1. The mortality rate among three age groups was studied in both male and female patients (Group I: < 40 years of age, Group II: 40-60 years of age, Group III: > 60 years). Results of the present study suggested that the mortality rate was higher $(\mathrm{P}<0.05)$ in males of group II compared to females of the same group. However, in groups I and III the mortality rate was similar $(\mathrm{P}>0.05)$ for both male and female patients.

Data on mortality rate from COVID-19 among different age groups irrespective of gender are presented in Figure 2 . The findings suggest that the mortality rate from COVID-19 increased $(\mathrm{P}<0.05)$ with the increase of age as it was higher among patients of 40-60 years (27 cases; $39.7 \%$ ) and $>60$ years ( 31 cases; $45.4 \%$ ) of age compared to patients of $<40$ years ( 10 cases; $14.7 \%$ ) of age.

\section{Discussion}

Previous studies from different regions suggest that the incidence of COVID-19 is not sex-biased (Wan et al., 2020; Wu et al., 2020). The authors suggest that the lack of gender difference might be due to the small sample size. However, in some countries, the incidence of COVID-19 is significantly higher in males compared to the female population (Mo et al., 2020; Chen et al., 2020a). The present study comprehensively explained the genderbased incidence, recovery period, and mortality rate from COVID-19. Our findings suggest that the incidence and mortality rate of COVID-19 is higher in males compared to female patients. Gender differences in the prevalence of different infectious diseases have been reported previously with a higher burden of viral, bacterial, fungal,

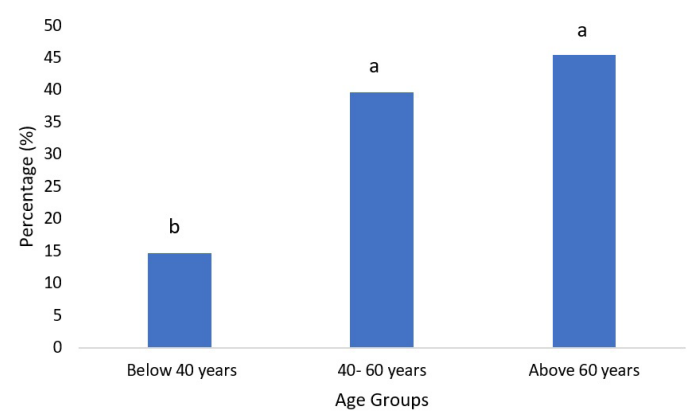

Figure 2. The mortality rate from COVID-19 among confirmed positive cases $(n=843)$ in different age groups among overall population visiting different hospitals of district Attock, Pakistan. Bars with different letters differ significantly $(\mathrm{p}<0.05)$.

and parasitic infections in human males (Schröder et al., 1998; Klein and Flanagan, 2016; Flanagan et al., 2017). A study of the first cases of COVID-19 in China showed its gender-based prevalence (Li et al., 2020). Another study (Chen et al., 2020a) reported a higher incidence of COVID-19 in males (73\%) compared to females (27\%). Scully et al. (2020) also reported that men are more affected with COVID-19 compared to women. The present study showed similar results among confirmed positive cases the incidence of COVID-19 was more prevalent in males (61.09\%) compared to females (38.90\%). Another study reported a higher prevalence of COVID-19 among males (58\%) compared to the female (42\%) population (Xu et al., 2020). Betron et al. (2020) reported that higher smoking rate, respiratory and heart disease, and weaker immune system and male sex hormones are some of the causes which contribute to COVID-19 increased incidence among males. Moreover, the presence of more ACE2 receptors in the lungs and heart of males compared to females makes them more vulnerable to severe disease (Sama et al., 2020). It is reported that when the SARS-CoV-2 virus binds with the ACE2 receptor of the host cell it creates a cellular doorway to infect the cell (Verdecchia et al., 2020). The presence of ACE2 receptors is reported to be higher in patients with heart disease, diabetes, and hypertension. As these diseases 
are comparatively higher in men compared to women it may explain the predominance of COVID-19 severity in males (Sama et al., 2020). Moreover, the presence of testosterone in males, being immunosuppressive, may explain the high prevalence of COVID-19 in the male gender (Klein et al., 2015). However, the impact of gender on SARS-CoV-2 is complicated and not fully understood.

The duration of infectious virus replication is one of the important factors in evaluating the risk of communication. Previous studies reported different results for recovery periods from COVID-19. In the present study, the average recovery period from COVID-19 was 18.89 days for males and 19.02 days for females. Similar to our findings another study suggested that the average recovery period from COVID-19 was 20 days among the Chinese population (Zhou et al., 2020). Another subsequent study conducted on the Chinese population reported that the average recovery period from COVID-19 was 26 days (Chen et al., 2020b). A study conducted in Ireland suggested the symptoms of COVID-19 may appear after 2 to14 days of exposure (Byrne et al., 2020). The difference among the recovery period of our results from the previous studies might be due to differences in the immunity development of the population residing in different countries.

In the present study, the mortality rate of COVID-19 was higher in males compared to the female population. Similar to the present study, Chen et al. (2020a) reported that the mortality rate of COVID-19 was higher in males compared to females. Similarly, the Hong Kong SARS-CoV-1 epidemic showed a high mortality ratio for males (Karlberg et al., 2004). The MERS outbreak also exhibited a predominance of mortality rate among males (52\%) compared to females (23\%) (Alghamdi et al., 2014). The high mortality rate of COVID-19 in males raises the question of whether males are in poor health conditions and are more vulnerable to different diseases. Other diseases like diabetes, cancer, liver, and heart diseases are more prevalent in males compared to females (Heron, 2019). Since these diseases have gender-based prevalence being higher in men (Dorak and Karpuzoglu, 2012; Wakabayashi, 2017), these comorbidities may explain the higher mortality of male patients from COVID-19. The other reason could be the immunosuppressive behavior of testosterone. Lower stress endurance levels in males may contribute to gender-biased pathogenesis of COVID-19 (Pradhan and Olsson, 2020). Another study from China reported that men are carrying more microbial pathogens compared to women among COVID-19 patients and these comorbidities may be a reason for the severity of COVID-19 in males (Li et al., 2020; Zhang et al., 2020). Females have more immunity-related genes and a stronger immune system and the presence of female sex hormone estrogen (Jaillon et al., 2019) helps them to combat viral infections that result in a lower mortality rate compared to males. Various genes present on X-chromosome have pattern recognition receptors (PRRs) as toll-like receptor 7 (TLR7), interleukin-1 receptorassociated kinase 1 (IRAK1), and TLR8 (Schurz et al., 2019; Taneja, 2018). The expression of TLR has been reported to be gender-specific as TLR3, TLR9, and TLR7 are found to be female-biased and they identify viral DNA and RNA which results in protection against viruses (Meier et al.,
2009; Taneja, 2018). This gene diversity among males and females may be one of the reasons for the gender-based prevalence of microbial pathogens. Moreover, both the innate and adaptive immune system is reported to be stronger in females compared to males that may be a reason for female gender benefit in COVID-19. The adaptive immune system of females have greater numbers of $\mathrm{CD} 4^{+}$ T cells (Abdullah et al., 2012; Ruel et al., 2011), the more strong cytotoxic activity of CD8 ${ }^{+} \mathrm{T}$ cell (Hewagama et al., 2009), and higher B cell production compared to males (Stoica et al., 1980; Abdullah et al., 2012). It indicates that females have a stronger ability to mount humoral immune responses than males.

In the present study, the mortality rate was higher $(\mathrm{P}<0.05)$ in males compared to females of same age group among the age group 40-60. In our findings, only 10 fatality cases ( $14.7 \%$ of total) were reported in patients aged less the 40 years, whereas a large number of cases were reported in patients aged 40-60 years (27 cases; $39.7 \%$ of total) and above 60 years of age (31 cases; $45.5 \%$ of total). Similar to our findings Levin et al. (2020) reported an exponential relationship between age and mortality rate of COVID-19 being very low in children and adults aged 25 but increases progressively at age $55,65,75$, and 85 respectively. Magalhães et al. (2020) reported that a large number of mortality cases ( 44 cases, $70 \%$ of total) were in patients aged 31 to 50 years. In another study from China, a higher mortality rate was reported in patients aged 70 to 79 years (Verity et al., 2020). Zhou et al. (2020) also reported that fatal cases of COVID -19 were concentrated in patients with the old age group. Previous studies reported that old age is an important factor in the mortality rate of MERS and SARS (Choi et al., 2003; Hong et al., 2018). In the present study the mortality rate from COVID-19 was higher $(\mathrm{P}<0.05)$ in patients aged $40-60$ years and above 60 years compared to patients below 40 years of age. Yu et al. (2020) reported that SARS-CoV-2 caused more viral replication in lung tissues and severe interstitial pneumonia in old macaque monkeys than in young ones. The plausible reason for the increased mortality rate with the increase of age might be due to immunosenescence. With the increase of age, the immune system weakens due to T-cell and B-cell defects and excessive production of cytokines by activated immune cells that ultimately results in poor control of viral replication (Opal et al., 2005). Besides aging immunity, other comorbid conditions also increase with the increase of age and it might be a reason for the increased mortality rate from COVID-19 in the elderly.

\section{Conclusion}

In conclusion due to weak innate and adaptive immune system, more angiotensin-converting enzyme 2 (ACE2) receptors, immunosuppressive sex hormone and other co-morbid conditions the incidence of COVID-19 was more in the male (61.09\%) compared to the female (38.90\%) population with an average recovery period of 19 days. The mortality rate from COVID-19 significantly increased with the increase of age. Moreover, the mortality rate from 
COVID-19 was significantly higher among males compared to the female population aged $40-60$ years.

\section{Acknowledgements}

The authors are thankful to the Information Department District Attock and Health Department Government of Punjab for the assistance in data collection. Special thanks to District Information Officer Attock, Mr. Shahzad Niaz for his valuable contribution to data collection.

\section{References}

ABDULLAH, M., CHAI, P.S., CHONG, M.Y., TOHIT, E.R.M., RAMASAMY, R., PEI, C.P. and VIDYADARAN, S., 2012. Gender effect on in vitro lymphocyte subset levels of healthy individuals. Cellular Immunology, vol. 272, no. 2, pp. 214-219. http://dx.doi. org/10.1016/j.cellimm.2011.10.009. PMid:22078320.

ALGHAMDI, I.G., HUSSAIN, I.I., ALMALKI, S.S., ALGHAMDI, M.S. ALGHAMDI, M.M. and EL-SHEEMY, M.A., 2014. The pattern of Middle East respiratory syndrome coronavirus in Saudi Arabia: a descriptive epidemiological analysis of data from the Saudi Ministry of Health. International Journal of General Medicine, vol. 7, pp. 417-423. http://dx.doi.org/10.2147/IJGM. S67061. PMid:25187734.

ARAB NEWS PK, 2020. Pakistan prepares to fight back as two coronavirus cases emerge in country. Arab News PK.

BETRON, M., GOTTERT, A., PULERWITZ, J., SHATTUCK, D. and STEVANOVIC-FENN, N., 2020. Men and COVID-19: adding a gender lens. Global Public Health, vol. 15, no. 7, pp. 10901092. http://dx.doi.org/10.1080/17441692.2020.1769702. PMid:32436422.

BIKDELI, B., MADHAVAN, M.V., JIMENEZ, D., CHUICH, T., DREYFUS, I., DRIGGIN, E., NIGOGHOSSIAN, C.D., AGENO, W., MADJID, M., GUO, Y., TANG, L.V., HU, Y., GIRI, J., CUSHMAN, M., QUÉRÉ, I., DIMAKAKOS, E.P., GIBSON, C.M., LIPPI, G., FAVALORO, E.J., FAREED, J., CAPRINI, J.A., TAFUR, A.J., BURTON, J.R., FRANCESE, D.P., WANG, E.Y., FALANGA, A., MCLINTOCK, C., HUNT, B.J., SPYROPOULOS, A.C., BARNES, G.D., EIKELBOOM, J.W., WEINBERG, I., SCHULMAN, S., CARRIER, M., PIAZZA, G., BECKMAN, J.A., STEG, P.G., STONE, G.W., ROSENKRANZ, S., GOLDHABER, S.Z., PARIKH, S.A., MONREAL, M., KRUMHOLZ, H.M., KONSTANTINIDES, S.V., WEITZ, J.I. and LIP, G.Y.H., 2020. COVID-19 and thrombotic or thromboembolic disease: implications for prevention, antithrombotic therapy, and follow-up: JACC state-of-the-art review. Journal of the American College of Cardiology, vol. 75, no. 23, pp. 2950-2973. http://dx.doi.org/10.1016/j.jacc.2020.04.031. PMid:32311448.

BYRNE, A.W., MCEVOY, D., COLLINS, A.B., HUNT, K., CASEY, M., BARBER, A., BUTLER, F., GRIFFIN, J., LANE, E.A., MCALOON, C., O'BRIEN, K., WALL, P., WALSH, K.A. and MORE, S.J., 2020. Inferred duration of infectious period of SARS-CoV-2: rapid scoping review and analysis of available evidence for asymptomatic and symptomatic COVID-19 cases. BMJ Open, vol. 10, no. 8, pp. e039856. http://dx.doi.org/10.1136/bmjopen-2020-039856. PMid:32759252.

CAI, G., 2019. Bulk and single-cell transcriptomics identify tobaccouse disparity in lung gene expression of ACE2, the receptor of 2019-nCov. medRxiv , vol. 33, no. 1, pp. 577-599. https://doi. org/10.1101/2020.02.05.20020107.

CAMPOS, D.M.O., OLIVEIRA, C.B.S., ANDRADE, J.M.A. and OLIVEIRA, J.I.N., 2020. Fighting COVID-19. Brazilian Journal of Biology =
Revista Brasileira de Biologia, vol. 80, no. 3, pp. 698-701. http:// dx.doi.org/10.1590/1519-6984.238155. PMid:32555974.

CHEN, N., ZHOU, M., DONG, X., QU, J., GONG, F., HAN, Y., QIU, Y., WANG, J., LIU, Y., WEI, Y., XIA, J., YU, T., ZHANG, X. and ZHANG, L., 2020a. Epidemiological and clinical characteristics of 99 cases of 2019 novel coronavirus pneumonia in Wuhan, China: a descriptive study. Lancet, vol. 395, no. 10223, pp. 507-513. http:// dx.doi.org/10.1016/S0140-6736(20)30211-7. PMid:32007143.

CHEN, T., WU, D., CHEN, H., YAN, W., YANG, D., CHEN, G., MA, K., XU, D., YU, H., WANG, H., WANG, T., GUO, W., CHEN, J., DING, C., ZHANG, X., HUANG, J., HAN, M., LI, S., LUO, X., ZHAO, J. and NING, Q., 2020b. Clinical characteristics of 113 deceased patients with coronavirus disease 2019: retrospective study. BMJ, vol. 368, pp. 1091. http://dx.doi.org/10.1136/bmj.m1091. PMid:32217556.

CHOI, K.W., CHAU, T.N., TSANG, O., TSO, E., CHIU, M.C., TONG, W.L., LEE, P.O., NG, T.K., NG, W.F., LEE, K.C., LAM, W., YU, W.C., LAI, J.Y. and LAI, S.T., 2003. Outcomes and prognostic factors in 267 patients with severe acute respiratory syndrome in Hong Kong. Annals of Internal Medicine, vol. 139, no. 9, pp. 715-723. http://dx.doi.org/10.7326/0003-4819-139-9-200311040-00005. PMid:14597455.

DORAK, M.T. and KARPUZOGLU, E., 2012. Gender differences in cancer susceptibility: an inadequately addressed issue. Frontiers in Genetics, vol. 3, pp. 268. http://dx.doi.org/10.3389/ fgene.2012.00268. PMid:23226157.

FLANAGAN, K.L., FINK, A.L., PLEBANSKI, M. and KLEIN, S.L., 2017. Sex and gender differences in the outcomes of vaccination over the life course. Annual Review of Cell and Developmental Biology, vol. 33, no. 1, pp. 577-599. http://dx.doi.org/10.1146/ annurev-cellbio-100616-060718. PMid:28992436.

GUAN, W.J., NI, Z.Y., HU, Y., LIANG, W.H., OU, C.Q., HE, J.X., LIU, L., SHAN, H., LEI, C.L., HUI, D.S., DU, B., LI, L.J., ZENG, G., YUEN, K.Y., CHEN, R.C., TANG, C.L., WANG, T., CHEN, P.Y., XIANG, J., LI, S.Y., WANG, J.L., LIANG, Z.J., PENG, Y.X., WEI, L., LIU, Y., HU, Y.H., PENG, P., WANG, J.M., LIU, J.Y., CHEN, Z., LI, G., ZHENG, Z.J., QIU, S.Q., LUO, J., YE, C.J., ZHU, S.Y. and ZHONG, N.S., 2020. Clinical characteristics of coronavirus disease 2019 in China. The New England Journal of Medicine, vol. 382, no. 18, pp. 1708-1720. http://dx.doi.org/10.1056/NEJMoa2002032. PMid:32109013.

HERON, M., 2019. Deaths: leading causes for 2017. National Vital Statistics Reports, vol. 68, no. 6, pp. 1-77. PMid:32501203.

HEWAGAMA, A., PATEL, D., YARLAGADDA, S., STRICKLAND, F.M. and RICHARDSON, B.C., 2009. Stronger inflammatory/cytotoxic T-cell response in women identified by microarray analysis. Genes and Immunity, vol. 10, no. 5, pp. 509-516. http://dx.doi. org/10.1038/gene.2009.12. PMid:19279650.

HONG, K.H., CHOI, J.P., HONG, S.H., LEE, J., KWON, J.S., KIM, S.M., PARK, S.Y., RHEE, J.Y., KIM, B.N., CHOI, H.J., SHIN, E.C., PAI, H., PARK, S.H. and KIM, S.H., 2018. Predictors of mortality in Middle East respiratory syndrome (MERS). Thorax, vol. 73, no. 3, pp. 286-289. http://dx.doi.org/10.1136/thoraxjnl-2016-209313. PMid:28724637.

HUANG, X., WEI, F., HU, L., WEN, L. and CHEN, K., 2020. Epidemiology and clinical characteristics of COVID-19. Archives of Iranian Medicine, vol. 23, no. 4, pp. 268-271. http://dx.doi.org/10.34172/ aim.2020.09. PMid:32271601.

JAILLON, S., BERTHENET, K. and GARLANDA, C., 2019. Sexual dimorphism in innate immunity. Clinical Reviews in Allergy E' Immunology, vol. 56, no. 3, pp. 308-321. http://dx.doi. org/10.1007/s12016-017-8648-x. PMid:28963611.

KARLBERG, J., CHONG, D.S.Y. and LAI, W.Y.Y., 2004. Do men have a higher case fatality rate of severe acute respiratory syndrome 
than women do? American Journal of Epidemiology, vol. 159, no. 3, pp. 229-231. http://dx.doi.org/10.1093/aje/kwh056. PMid:14742282.

KLEIN, S.L. and FLANAGAN, K.L., 2016. Sex differences in immune responses. Nature Reviews. Immunology, vol. 16, no. 10, pp. 626638. http://dx.doi.org/10.1038/nri.2016.90. PMid:27546235.

KLEIN, S.L., MARRIOTT, I. and FISH, E.N., 2015. Sex-based differences in immune function and responses to vaccination. Transactions of the Royal Society of Tropical Medicine and Hygiene, vol. 109, no. 1, pp. 9-15. http://dx.doi.org/10.1093/trstmh/tru167. PMid:25573105.

LEVIN, A.T., HANAGE, W.P., OWUSU-BOAITEY, N., COCHRAN, K.B., WALSH, S.P. and MEYEROWITZ-KATZ, G., 2020. Assessing the age specificity of infection fatality rates for COVID-19: systematic review, meta-analysis, and public policy implications. European Journal of Epidemiology, vol. 35, no. 12, pp. 1123-1138. http:// dx.doi.org/10.1007/s10654-020-00698-1. PMid:33289900.

LI, X., XU, S., YU, M., WANG, K., TAO, Y., ZHOU, Y., SHI, J., ZHOU, M., WU, B., YANG, Z., ZHANG, C., YUE, J., ZHANG, Z., RENZ, H., LIU, X., XIE, J., XIE, M. and ZHAO, J., 2020. Risk factors forseverity and mortality in adult covid-19 inpatients in Wuhan. The Journal of Allergy and Clinical Immunology, vol. 146, no. 1, pp. 110-118. http://dx.doi.org/10.1016/j.jaci.2020.04.006. PMid:32294485.

MAGALHÃES, D.M., NUNES-SILVA, A., ROCHA, G.C., VAZ, L.N., DE FARIA, M.H.S., VIEIRA, E.L.M., ROCHA, N.P. and SIMÕES E SILVA, A.C., 2020. Two protocols of aerobic exercise modulate the counter-regulatory axis of the renin-angiotensin system. Heliyon, vol. 6, no. 1, pp. e03208. http://dx.doi.org/10.1016/j. heliyon.2020.e03208. PMid:31989052.

MEIER, A., CHANG, J.J., CHAN, E.S., POLLARD, R.B., SIDHU, H.K., KULKARNI, S., WEN, T.F., LINDSAY, R.J., ORELLANA, L., MILDVAN, D., BAZNER, S., STREECK, H., ALTER, G., LIFSON, J.D., CARRINGTON, M., BOSCH, R.J., ROBBINS, G.K. and ALTFELD, M., 2009. Sex differences in the Toll-like receptor-mediated response of plasmacytoid dendritic cells to HIV-1. Nature Medicine, vol. 15, no. 8, pp. 955-959. http://dx.doi.org/10.1038/nm.2004. PMid:19597505.

MO, P., XING, Y., XIAO, Y., DENG, L., ZHAO, Q., WANG, H., XIONG, Y., CHENG, Z., GAO, S., LIANG, K., LUO, M., CHEN, T., SONG, S., MA, Z., CHEN, X., ZHENG, R., CAO, Q., WANG, F. and ZHANG, Y., 2020. Clinical characteristics of refractory COVID-19 pneumonia in Wuhan, China. Clinical Infectious Diseasesm ciaa270. http:// dx.doi.org/10.1093/cid/ciaa270. PMid:32173725.

MUGHAL, S., 2020. Coronavirus outbreak: Pakistan sets up scanners at major airports. At least four patients have tested positi ve for COVID-19 in Pakistan [online]. The Express Tribune, Karachi, 1 mar. Available from: https://tribune.com.pk/story/2167237/1 coronavirus-outbreak-pakistan-sets-scanners-major-airports/

OMOLO, C.A., SONI, N., FASIKU, V.O., MACKRAJ, I. and GOVENDER, T. 2020. Update on therapeutic approaches and emerging therapies for SARS-CoV-2 virus. European Journal of Pharmacology, vol. 883, pp. 173348. http://dx.doi.org/10.1016/j.ejphar.2020.173348. PMid:32634438.

OPAL, S.M., GIRARD, T.D. and ELY,E.W., 2005. The immunopathogenesis of sepsis in elderly patients. Clinical infectious diseases, vol. 41, no. Supplement, vol. 7, pp. S504-S512.

PRADHAN, A. and OLSSON, P.E., 2020. Sex differences in severity and mortality from COVID-19: are males more vulnerable? Biology of Sex Differences, vol. 11, no. 1, pp. 53. http://dx.doi. org/10.1186/s13293-020-00330-7. PMid:32948238.

RICKMAN, H.M., RAMPLING, T., SHAW, K., MARTINEZ-GARCIA, G., HAIL, L., COEN, P., SHAHMANESH, M., SHIN, G.Y., NASTOULI, E. and HOULIHAN, C.F., 2021. Nosocomial transmission of coronavirus disease 2019: a retrospective study of 66 hospitalacquired cases in a London teaching hospital. Clinical Infectious Diseases, vol. 72, no. 4, pp.690-693. http://dx.doi.org/10.1093/ cid/ciaa816. PMid:32562422.

RUEL, T.D., ZANONI, B.C., SSEWANYANA, I., CAO, H., HAVLIR, D.V., KAMYA, M., ACHAN, J., CHARLEBOIS, E.D. and FEENEY, M.E., 2011. Sex differences in HIV RNA level and CD4 cell percentage during childhood. Clinical Infectious Diseases, vol. 53, no. 6, pp. 592-599. http://dx.doi.org/10.1093/cid/cir484. PMid:21840929.

SAMA, I.E., RAVERA, A., SANTEMA, B.T., VAN GOOR, H., TER MAATEN, J.M., CLELAND, J.G., RIENSTRA, M., FRIEDRICH, A.W., SAMANI, N.J., NG, L.L., DICKSTEIN, K., LANG, C.C., FILIPPATOS, G., ANKER, S.D., PONIKOWSKI, P., METRA, M., VAN VELDHUISEN, D.J. and VOORS, A.A., 2020. Circulating plasma concentrations of angiotensin-converting enzyme 2 in men and women with heart failure and effects of renin-angiotensin-aldosterone inhibitors. European Heart Journal, vol. 41, no. 19, pp. 1810-1817. http://dx.doi.org/10.1093/eurheartj/ehaa373. PMid:32388565.

SCHRÖDER, J., KAHLKE, V., STAUBACH, K.H., ZABEL, P. and STÜBER, F., 1998. Gender differences in human sepsis. Archives of Surgery, vol. 133, no. 11, pp. 1200-1205. http://dx.doi.org/10.1001/ archsurg.133.11.1200. PMid:9820351.

SCHURZ, H., SALIE, M., TROMP, G., HOAL, E.G., KINNEAR, C.J. and MOLLER, M., 2019. The x chromosome and sex-specific effects in infectious disease susceptibility. Human Genomics, vol. 13, no. 1, pp. 2. http://dx.doi.org/10.1186/s40246-018-0185-z. PMid:30621780.

SCULLY, E.P., HAVERFIELD, J., URSIN, R.L., TANNENBAUM, C. and KLEIN, S.L., 2020. Considering how biological sex impacts immune responses and COVID-19 outcomes. Nature Reviews. Immunology, vol. 20, no. 7, pp. 442-446. http://dx.doi. org/10.1038/s41577-020-0348-8. PMid:32528136.

STOICA, G., MACARIE, E., MICHIU, V. and STOICA, R.C., 1980. Biologic variation of human immunoglobulin concentration. I. Sexage specific effects on serum levels of IgG, IgA, IgM and IgD. Medecine Interne, vol. 18, no. 3, pp. 323-332. PMid:7414242.

TANEJA, V., 2018. Sex hormones determine immune response. Frontiers in Immunology, vol. 9, pp. 1931. http://dx.doi. org/10.3389/fimmu.2018.01931. PMid:30210492.

VERDECCHIA, P., CAVALLINI, C., SPANEVELLO, A. and ANGELI, F., 2020. The pivotal link between ACE2 deficiency and SARS-CoV-2 infection. European Journal of Internal Medicine, vol. 76, pp. 14-20. http://dx.doi.org/10.1016/j.ejim.2020.04.037. PMid:32336612.

VERITY, R., OKELL, L.C., DORIGATTI, I., WINSKILL, P., WHITTAKER, C., IMAI, N., CUOMO-DANNENBURG, G., THOMPSON, H., WALKER, P.G., FU, H., DIGHE, A., GRIFFIN, J.T., BAGUELIN, M., BHATIA, S., BOONYASIRI, A., CORI, A., CUCUNUBÁ, Z., FITZJOHN, R., GAYTHORPE, K., GREEN, W., HAMLET, A., HINSLEY, W., LAYDON, D., NEDJATI-GILANI, G., RILEY, S., VAN ELSLAND, S., VOLZ, E., WANG, H., WANG, Y., XI, X., DONNELLY, C.A., GHANI, A.C. and FERGUSON, N.M., 2020. Estimates of the severity of coronavirus disease 2019: a model-based analysis. The Lancet. Infectious Diseases, vol. 20, no. 6, pp. 669-677. http://dx.doi.org/10.1016/ S1473-3099(20)30243-7. PMid:32240634.

WAKABAYASHI, I., 2017. Gender differences in cardiovascular risk factors in patients with coronary artery disease and those with type 2 diabetes. Journal of Thoracic Disease, vol. 9, no. 5, pp. E503-E506. http://dx.doi.org/10.21037/jtd.2017.04.30. PMid:28616322.

WAN, S., XIANG, Y.I., FANG, W., ZHENG, Y., LI, B., HU, Y., LANG, C., HUANG, D., SUN, Q., XIONG, Y., HUANG, X., LV, J., LUO, Y., SHEN, L., YANG, H., HUANG, G. and YANG, R., 2020. Clinical features and treatment of COVID-19 patients in northeast Chongqing. Journal of Medical Virology, vol. 92, no. 7, pp. 797-806. http:// dx.doi.org/10.1002/jmv.25783. PMid:32198776. 
WANG, D., HU, B., HU, C., ZHU, F., LIU, X., ZHANG, J., WANG, B., XIANG H., CHENG, Z., XIONG, Y., ZHAO, Y., LI, Y., WANG, X. and PENG, Z., 2020a. Clinical characteristics of 138 hospitalized patients with 2019 novel coronavirus-infected pneumonia in Wuhan, China. Journal of the American Medical Association, vol. 323, no. 11, pp. 1061 1069. http://dx.doi.org/10.1001/jama.2020.1585. PMid:32031570.

WANG, Z., WANG, J. and HE, J., 2020b. Active and effective measures for the care of patients with cancer during the COVID-19 spread in China. The Journal of the American Medical Association Oncology, vol. 6, no. 5, pp. 631-632. PMid:32236504.

WORLD HEALTH ORGANIZATION - WHO, 2020. Coronavirus disease 2019 (COVID-19): situation report. Geneva: WHO. no. 46. [online]. Available from: https://apps.who.int/iris/handle/10665/331443

WU, J., LIU, J., ZHAO, X., LIU, C., WANG, W., WANG, D., XU, W. ZHANG, C., YU, J., JIANG, B., CAO, H. and LI, L., 2020. Clinical characteristics of imported cases of coronavirus disease 2019 (COVID-19) in Jiangsu Province: a multicenter descriptive study. Clinical Infectious Diseases, vol. 71, no. 15, pp. 706-712. http:// dx.doi.org/10.1093/cid/ciaa199. PMid:32109279.

XU, K., CHEN, Y., YUAN, J., YI, P., DING, C., WU, W., LI, Y., NI, Q., ZOU, R., LI, X., XU, M., ZHANG, Y., ZHAO, H., ZHANG, X., YU, L., SU, J., LANG, G., LIU, J., WU, X., GUO, Y., TAO, J., SHI, D., YU, L., CAO, Q., RUAN, B., LIU, L., WANG, Z., XU, Y., LIU, Y., SHENG, J. and LI, L., 2020. Factors associated with prolonged viral RNA shedding in patients with coronavirus disease 2019 (COVID-19). Clinical Infectious Diseases, vol. 71, no. 15, pp. 799-806. http://dx.doi. org/10.1093/cid/ciaa351. PMid:32271376.
YU, R., CHEN, L., LAN, R., SHEN, R. and LI, P., 2020. Computational screening of antagonists against the SARS-CoV-2 (COVID-19) coronavirus by molecular docking. International Journal of Antimicrobial Agents, vol. 56, no. 2, pp. 106012. http://dx.doi. org/10.1016/j.ijantimicag.2020.106012. PMid:32389723.

ZHANG,J.J., DONG, X., CAO, Y.Y., YUAN, Y.D., YANG, Y.B., YAN, Y.Q., AKDIS, C.A. and GAO, Y.D., 2020. Clinical characteristics of 140 patients infected with SARS-CoV-2 in Wuhan, China. Allergy, vol. 75, no. 7, pp. 1730-1741. http://dx.doi.org/10.1111/all.14238. PMid:32077115.

ZHAO, Y., ZHAO, Z., WANG, Y., ZHOU, Y., MA, Y. and ZUO, W., 2020. Single-cell RNA expression profiling of ACE2, the receptor of SARS-CoV-2. American Journal of Respiratory and Critical Care Medicine, vol.202, no. 5, pp. 756-759. http://dx.doi.org/10.1164/ rccm.202001-0179LE.

ZHOU, F., YU, T., DU, R., FAN, G., LIU, Y., LIU, Z., XIANG, J., WANG, Y., SONG, B., GU, X., GUAN, L., WEI, Y., LI, H., WU, X., XU, J., TU, S., ZHANG, Y., CHEN, H. and CAO, B., 2020. Clinical course and risk factors for mortality of adult inpatients withCOVID-19 in Wuhan, China: a retrospective cohort study. Lancet, vol. 395, no. 10229, pp. 1054-1062. http://dx.doi.org/10.1016/S01406736(20)30566-3. PMid:32171076.

ZHU, N., ZHANG, D., WANG, W., LI, X., YANG, B., SONG, J., ZHAO, X., HUANG, B., SHI, W., LU, R., NIU, P., ZHAN, F., MA, X., WANG, D., XU, W., WU, G., GAO, G.F. and TAN, W., 2020. A novel coronavirus from patients with pneumonia in China, 2019. The New England Journal of Medicine, vol. 382, no. 8, pp. 727-733. http://dx.doi. org/10.1056/NEJMoa2001017. PMid:31978945. 